\title{
THE INFLUENCE OF CURRENT RATIO, INVENTORY TURNOVER RATIO, CASH TURNOVER AND DEBT TO EQUITY RATIO AGAINST THE RETURN ON INVESTMENT IN THE PRODUCTION OF INDUSTRIAL COMPANIES LISTED ON THE STOCK EXCHANGE OF MALAYSIA IN 2016
}

\author{
Rika Umniati ${ }^{1}$, Kartika Hendra Titisari ${ }^{2}$, Yuli Chomsatu ${ }^{3}$ \\ ${ }^{123}$ Program Studi Akuntansi S1, Fakultas Ekonomi, Universitas Islam Batik Surakarta \\ Jl. KH. Agus Salim No. 10, Surakarta 57147, Jawa Tengah, Indonesia \\ *E-mail : rikaumni@gmail.com
}

\begin{abstract}
This research aims to know the influence of Current Ratio, Inventory Turnover Ratio, Cash Turnover and Debt To Equity Ratio against the Return On Investment. The population in the study, namely the production of industrial companies listed on the stock exchange of Malaysia Year 2016 totalling 233 companies. Type of this research is quantitative research. Sampling using a purposive sampling technique. The number of samples as many as 131 research company. Methods of data analysis used in the study are using multiple linear regression test. Data analysis using SPSS 17 assistance. The results of this study indicate that a variable Inventory Turnover Ratio effect on Return On Investment. While the Current Ratio, variable Cash Turnover and Debt To Equity Ratio has no effect against a Return On Investment.
\end{abstract}

Keywords: Current Ratio, Inventory Turnover Ratio, Cash Turnover, Debt To Equity Ratio, Return On Investment

\begin{abstract}
Abstraksi-Penelitian ini bertujuan untuk mengetahui pengaruh Current Ratio, Rasio Perputaran Persediaan, Perputaran Kas dan Rasio Hutang terhadap Ekuitas terhadap Return On Investment. Populasi dalam penelitian, yaitu produksi perusahaan industri yang terdaftar di bursa efek Malaysia Tahun 2016 berjumlah 233 perusahaan. Jenis penelitian ini adalah penelitian kuantitatif. Pengambilan sampel menggunakan teknik purposive sampling. Jumlah sampel sebanyak 131 perusahaan penelitian. Metode analisis data yang digunakan dalam penelitian ini menggunakan uji regresi linier berganda. Analisis data menggunakan bantuan SPSS 17. Hasil penelitian ini menunjukkan bahwa variabel Inventory Turnover Ratio berpengaruh terhadap Return On Investment. Sedangkan Current Ratio, variabel Cash Turnover dan Debt To Equity Ratio tidak berpengaruh terhadap Return On Investment.
\end{abstract}

Kata Kunci: Current Ratio, Inventory Turnover Ratio, Cash Turnover, Debt To Equity Ratio, Return On Investment

\section{INTRODUCTION}

In the current era of globalization, the (Elnisyah, 2014)world of business was booming and the competition is so tight. In General, each company has a principal purpose i.e. can maximise profits and the value of the company for the sake of the continuity of his efforts. Therefore, the company should be able to improve the performance of the company in order to sustain the effort. The parameters used to assess financial performance using financial information obtained from the financial reports were analyzed with the tools of financial analysis.

Financial performance evaluation can be done using the analysis of the financial statements. Analysis of financial statements can be made using financial ratios. Ratio-ratio used in this study using a ratio of profitability, liquidity, solvency and activity. Profitability ratios in the study is represented by the Return On Investment (ROI) and the dependent variable is used as a study.

Liquidity ratios in the study is represented by the Current Ratio. According to Kasmir (2010) current ratio is a ratio to measure the company's ability to pay short-term obligations or debts immediately due upon billed in its entirety. In other words how much current assets available to cover short-term obligations that are immediately due. In the Pamungkas \& 
Sukirno (2016) research, Saputra (2013) and Febriano (2014) results showed significant effect against the Current Ratio of Return On Investment. So the H1 Current Ratio influence to the Return On Investment.

The ratio of the activity represented by the Inventory Turnover Ratio (ITR). Turnover ratio is the ratio of the Invertory used to measure the number of times the funding that was planted in the preparations (inventory) is spinning in one period. This ratio is known as the ratio of rotation of stocks. Can be interpreted as that turnover is the ratio of stocks to which shows how many times the number of any material replaced in one year (Kasmir, 2010). If the increasing inventory turnover or the faster the spin, then the company is operating optimally, so being able to increase profits to be generated. Research Saputra (2013) shows that the Inventory Turnover Ratio effect significantly to Return On Investment (ROI). $\mathrm{H}_{2}$ : inventory turnover ratio influence to the Return On Investment.

Cash Turnover is one of the indicators to measure liquidity ratio. Cash turnover ratio according to James o. Gill in Kasmir (2010) is used to measure the degree of sufficiency of working capital the company needed to pay bills and fund sales. That is, this ratio is used to measure the level of availability of cash to pay the Bills (debt) and costs related to the sale. The faster rotation of the cash it will generate the maximum profit. This is because cash spin rapidly in a certain period can result in a high level of sales so that the company will earn a bigger profit. Research conducted Fitri, Supriyanto, \& Abrar (2016) shows that the Cash Turnover effect significantly to levels of profitability. H3 : Cash Turnover influence to the Return On Investment.

Solvency ratio represented by Debt to Equity Ratio (DER). Debt to equity ratio is a ratio used to assess the debt with equity. To find this ratio with how to compare between the entire debt, including debt smoothly with the rest of the equity. This ratio is useful to know the amount of funding provided the borrower (creditors) and owner of the company. In other words the ratio is aware of any own capital was made rupiah to guarantee debt (Kasmir, 2010). The higher the Debt To Equity Ratio will then affect the magnitude of the earnings of the acquired company. Of the concept suggests that the Debt To Equity Ratio positiv effect against profitability (Return On Investment) and supported by the Pamungkas \& Sukirno (2016) and Febriano (2014) research, it can be formulated H4 : Debt To Equity Ratio influence to the Return On Investment.

Based on previous researchers with results still contradictory, then researchers want to test back on the influence of financial ratio (Current Ratio, Inventory Turnover Ratio, Cash Turnover and Debt To Equity Ratio) of profitability (Return On Investment). This research was conducted on production of industrial companies listed on the stock exchange of Malaysia. The reason this sector of the pick because the production facility in Malaysia is the largest major manufacturing center after France. In addition industrial production was the largest issuer group compared to other groups.

\section{METHODOLOGY}

Types of causal research is comparative. The source of the data used in this research is secondary data. The data used is found in the financial report of year 2016 production industrial companies listed on the stock exchange of Malaysia and has been audited. Data can be accessed through the official website of the Malaysian stock exchange, namely www.bursamalaysia.com. The dependent variable in this study is the ratio of profitability with measured using Return On Investment (ROI). While the independent variable research i.e. Current Ratio, Inventory Turnover Ratio, Cash Turnover and Debt To Equity Ratio.

The population in this research is the production of industrial companies all registered in the stock exchange of Malaysia during the research period of the year 2016 . Sampling in research using a purposive sampling technique. The criteria in the sampling in research is to 1) The company published financial statements respectively and have been audited during the research period 2016, 2) Company did not acquire negative earnings during the period of observation that is years 2016, 3) The company has a complete data during the period of observation 
according canvassed variable. Based on the criteria specified above, then the number of samples in the study as much as 132 company.

Methods of data analysis using descriptive statistics test, classic assumption test and regression analysis. Descriptive statistical tests used to calculate or measure the various characteristics of data with other data between the value of the sum, the mean, standard deviation, variance, range, the minimum value and maximum. A classic assumption test consists of normality test i.e to test whether the regression model is normally distributed or not, using the Kolmogorov-Smirnov test statistics Test. If significant numbers Kolmogorov-Smirnov Test $>0.05$ data shows distributed normally.

Multicollinearity test aimed at testing whether in regression models found the existence of a correlation between free variables (independent) (Ghozali, 2009). The presence of multicollinearity can be viewed from the value of the tolerance or the Variance Inflation Factor (VIF). If the value of tolerance $>10 \%(0.01)$ or VIP $<10$ then said no symptoms of multicollinearity in regression models.

Heteroskedastisitas test aims to test whether the model regression residual variance inequality occurs from one observation to another observation (Ghozali, 2009). Test your heteroskedastisitas can be tested using a test Scatterplot. To determine whether or not there are symptoms of heteroskedastisitas by way of a scatterplot graph see patterns. Provision of data does not occur when the symptoms of heteroskedastisitas is 1) Data points in deployment around the numbers 0 or above and below the numbers 0,2 ) No data points gathered above or below it, 3) In the dissemination of the data points do not form a wavy pattern widens and then narrows and widens again, 4) Promised the data points do not form a pattern.

Autokolerasi test function to test whether a linear regression model in one there is a correlation between the error in period $t$ by mistake the previous period. One of the tests that are used to the presence of autocorrelation is using runs test. If the value is significant, then the $0.05>$ can be concluded that there are no symptoms of autokolerasi of regression models.
Regression analysis consists of multiple regression analysis namely aiming to find out the direction of the relationship between the dependent variable independent variable. The formula used for this analysis is shown in equation:

$\mathrm{Y}=\mathrm{a}+\mathrm{b}_{1} \mathrm{CR}+\mathrm{b}_{2} \mathrm{ITR}+\mathrm{b}_{3} \mathrm{CT}+\mathrm{b}_{4} \mathrm{DER}+\mathrm{e}$

Description:

$\mathrm{Y}=$ Return On Investment

A $=$ Constant

$\mathrm{b}=$ Regression Coefficient

$\mathrm{CR}=$ Current Ratio

ITR = Inventory Turnover Ratio

$\mathrm{CT}=$ Cash Turnover

DER = Debt To Equity Ratio

e $\quad=$ Error

Feasibility test model using $\mathrm{F}$ test. $\mathrm{F}$ Test aims to test whether all the independent variable in the study used in the regression models have simultaneously (together) against the dependent variable. If the probability value of significance $<0,05$, it can be concluded that the model is feasible.

Hypothesis test using $t$ test. Statistical $t$ test done to know the influence of each variable are independent of the dependent variable (Ghozali, 2009). One of the tests used by comparing the significance probability value $t$ with a degree of confidence. If the value of significance $>0.05$, then $\mathrm{H}_{0}$ are received. Whereas if the value significance $<0.05, \mathrm{H}_{0}$ is rejected.

Coefficient Determination Test $\left(\mathrm{R}^{2}\right)$ to measure how far the capability model in the dependent variables that describe the variations are examined. The value of the coefficient of determination is seen from the magnitude of the adjusted $r$ square, with values ranging between zero and one. The adjusted $r$ square value approaching 1 shows the independent variables giving almost all the information needed to predict the dependent variable.

\section{RESULT AND DISCUSSIONS}

The study was prepared with the help of SPSS 17. Based on selection criteria samples, then retrieved the sample as much as 131 production industrial companies listed on the stock exchange of Malaysia year 2016. 
Table 1 The Results of Descriptive Statistic

\begin{tabular}{cccccc}
\hline Variable & $\mathbf{N}$ & Minimum & Maximum & Mean & Std. Deviation \\
\hline CR & 131 & 0,04 & 185,05 & 5,8298 & 19,36407 \\
ITR & 131 & 0,05 & 82,10 & 6,3281 & 7,81529 \\
CT & 131 & 0,05 & 97,36 & 7,8985 & 9,40667 \\
DER & 131 & 0,03 & 3,94 & 0,6316 & 0,62977 \\
ROI & 131 & 0,00 & 203,62 & 4,3035 & 20,82300 \\
\hline
\end{tabular}

Table 2 The Results of Normality Test

\begin{tabular}{ccccc}
\hline Variable & N & Sig & Std & Description \\
\hline $\begin{array}{c}\text { Unstandardized } \\
\text { Residual }\end{array}$ & 131 & 0,525 & $>0,05$ & $\begin{array}{c}\text { Data is distributed } \\
\text { normally }\end{array}$ \\
\hline
\end{tabular}

Table 3 Results of test for Multicollinearity

\begin{tabular}{cccccc}
\hline Variable & Tolerance & Std & VIF & Std & Description \\
\hline CR & 0,957 & $>0,01$ & 1,045 & $<10$ & No multicollinearity \\
ITR & 0,527 & $>0,01$ & 1,896 & $<10$ & No multicollinearity \\
CT & 0,529 & $>0,01$ & 1,890 & $<10$ & No multicollinearity \\
DER & 0,961 & $>0,01$ & 1,041 & $<10$ & No multicollinearity \\
\hline
\end{tabular}

\section{Descriptive Statistics}

Descriptive statistics are used to describe the characteristics of the data from the variables of the study. Based on the test results of the descriptive statistics in table 1 shows that the variable Current Ratio (CR) the minimum value 0,04 maximum value 185.05 with average (mean) of 5.8298 and standard deviation value 19,36407 of data 131. Variable Inventory Turnover Ratio (ITR) has a minimum value 0.05 , maximum value 82,10 with average (mean) of 6.3281 and the level of standard deviation 7.81529. Variable Cash Turnover (CT) minimum value 0.05 , maximum value 97.36 , average (mean) 7.8985 and the value of the standard deviation of 9.40667. Variable Debt To Equity Ratio has the minimum value 0,03 and maximum value 3.94 , average value 0.6316 and value standard deviation of 0.62977 . While the variable is Return On Investment (ROI) have a minimum value of 0.00 , values of maximum 203.62 with average (mean) 4.3035 and standard deviation 20.82300 from the amount of data 131 .

\section{Classic Assumption Test}

\section{Normality Test}

Normality test using KolmogorovSmirnov Test by looking at significnce value. If the numbers are significant, KolmogorovSmirnov Test $>0.05$ then distributed data shows normal. Normality test results can be presented in a table 2 .

Based on table 2 results of test of normality indicate that variable unstandardized residual value for sig 0.525 i.e greater than the standard value of 0.05 , then it can be inferred that the research data is distributed normally.

\section{Multicollinearity Test}

Based on table 3 test results indicate that multicollinearity variable Current Ratio (CR) has value tolerance 0.957 greater than 0.01 and VIF of 1.045 less than 10. Inventory Turnover Ratio has value tolerance 0.527 greater than 0.01 and VIF of 1.896 less than 10. While the Cash Turnover variable (CT) value tolerance 0.529 greater than 0.01 and the value of VIF 1.890 less than 10. Debt To Equity Ratio variable value tolerance 0.961 greater than 0.01 and VIF of 1.041 was less than 10. It can be inferred that the independent variable (free) in the study there were no symptoms of multicollinearity.

\section{Heteroskedastisitas Test}

Based on the picture above scatterplots show that data points spread around the numbers 0 or above and below the 0 on the $\mathrm{Y}$ axis and the promised data points do not form a pattern. Then it can be inferred that the regression model does not occur heteroskedastisitas symptoms. 


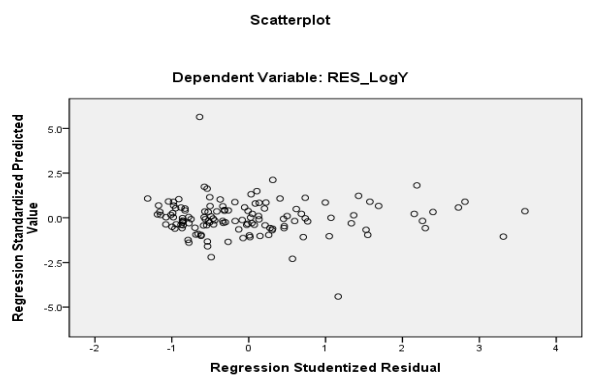

Table 4 results of Test Autocorrelation

\begin{tabular}{ccccc}
\hline Variable & N & Sig & Std & Description \\
\hline Unstandardized Residual & 131 & 0,540 & $>0,05$ & No Autocorrelation \\
\hline
\end{tabular}

Table 5 The Results Multiple Linear regression test

\begin{tabular}{ccc}
\hline Variable & B & Sig \\
\hline Constant & $-6,323$ & 0,007 \\
CR & 0,024 & 0,729 \\
ITR & 3,130 & 0,002 \\
CT & $-1,038$ & 0,210 \\
DER & $-1,773$ & 0,397 \\
\hline
\end{tabular}

\section{Autocorrelation Test}

One of the autocorrelation test using runs test with the provisions if the value significantly $>0.05$, then it can be inferred that no symptoms of autokolerasi of regression models. Autocorrelation test results can be presented in the table 4.

Based on autocorrelation test results at table 4 indicate the residual unstandardardized variable has the value of sig 0,540 amount of 131 data. Sig value greater than the default value $(0.540>0.05)$, then it can be inferred that the symptom does not occur in a regression model of the autocorrelation.

\section{Regression Analysis}

\section{Multiple Linear regression analysis}

Based on the results of multiple linear regression test at table 5, then the regression equiation as follows:

$\mathrm{Y}=-6.323+\mathrm{CR}+0.0243 .130 \mathrm{ITR}-1.038$

$\mathrm{CT}-1.773 \mathrm{DER}+\mathrm{e}$

The regression equation formed has meaning :

1. Constants (a) registration -6.323 pointed out that all the dependent variable is 0 , then the rate of Return On Investments of -6.323 .
2. Regression coefficients of magnitude Current Ratio (CR) positive value of 0.024 . A positive value indicates that if the variable Current Ratio rose by 1 percent assuming the other variables fixed, it will be followed by the increase in Return On Investment of 0.024 .

3. Regression coefficient value Inventory Turnover Ratio (ITR) is positive of 3.130. A positive value indicates that if a variable Inventory Turnover Ratio rose by 1 percent assuming the other variables fixed, it will be followed by the increase in Return On Investment of 3.130.

4. The magnitude of the coefficients of regression Cash Turnover (CT) is negative of 1.038. A negative value indicates that if the variable Cash Turnover dropped by 1 percent assuming the other variables fixed, then followed a decline in Return On Investment amounted to 1.038.

5. Regression coefficients of magnitude Debt To Equity Ratio is negative amounting-1.773. Negative values indicate that in variable Debt To Equity Ratio dropped by 1 percent assuming the other variables fixed, then followed a decrease in the Return On Investment of 1.773 . 
Table 6 test results $\mathrm{F}$

\begin{tabular}{cccccc}
\hline Model & $\mathbf{F}_{\text {count }}$ & $\mathbf{F}_{\text {table }}$ & Sig & Std & Description \\
\hline 1 & 34,102 & 2,44 & 0,000 & $<0,05$ & The model is feasible \\
\hline
\end{tabular}

Table 7 The Result $t$ test

\begin{tabular}{|c|c|c|c|c|c|}
\hline Variable & $\mathrm{t}_{\text {count }}$ & $\mathrm{t}_{\text {table }}$ & $\mathrm{Sig}$ & Std & Description \\
\hline $\mathrm{H}_{1}$ & 0,348 & 1,97897 & 0,729 & $<0,05$ & Rejected \\
$\mathrm{H}_{2}$ & 3,160 & 1,97897 & 0,002 & $<0,05$ & Accepted \\
$\mathrm{H}_{3}$ & $-1,260$ & 1,97897 & 0,210 & $<0,05$ & Rejected \\
$\mathrm{H}_{4}$ & $-0,850$ & 1,97897 & 0,397 & $<0,05$ & Rejected \\
\hline
\end{tabular}

\section{Model Feasibility Test (F Test)}

Feasibility test of the model using the test of F. F Test aims to find out the influence of simultaneously or together between the independent variable (of the dependent variable. Test results of $\mathrm{F}$ in the study are presented in the table 6.

Based on test results of table $6 \mathrm{~F}$ test obtained $\mathrm{F}_{\text {count }}$ of 34,102 while $\mathrm{F}_{\text {table }}$ of 2.44 . This shows that $\mathrm{F}_{\text {count }}>\mathrm{F}_{\text {table }}(34.102>2.44)$ significance and value of 0.000 smaller than 0.05 . Then it can be inferred the regression models in research.

\section{Hypothesis Test (t test)}

$T$ test aims to find out the influence of the variables are independent of partially variable. Based on the results of the t test in table 7 above, can be described respectively as the following hypothesis:

\section{The First Hypotesis (H1) : Influence Current Ratio against the Return On Investment}

This test aims to prove whether the Current Ratio effect partially against the Return On Investment. Based on the results of table 7 above obtained $t_{\text {count }}$ value of 0.348 while $t_{\text {table }}$ value 1.97897 , the significance $72,9 \%$. Then it can be inferred that the $\mathrm{H} 1$ denied or there are no partially influence between Current Ratio against the Return On Investment.

Research results from research in line with the Elnisyah (2014), Pamungkas \& Sukirno (2016) stating that the Current Ratio effect on Return On Investment. But research Saputra (2013) and Febriano (2014) found contradictory results that the Current Ratio effect on Return On Investment.

While the results of this study make it clear that if the value of Current Ratio the lower the value the ROI will decrease. In this case it means companies in the management of the Fund, there is still less than optimal assets that have not been used. Management of the Fund are less than optimal result in the ability of the company's declining profit that have an impact on the profitability of the company. The low level of profitability will affect to meet current liabilities on a timely basis.

\section{The Second Hypotesis (H2) : Influence of the Inventory Turnover Ratio against the Return On Investment}

This test aims to prove whether there is a partial influence between Inventory Turnover Ratio against the Return On Investment. Based on the test results in table 7 above obtained $\mathrm{t}_{\text {count }}$ value while $3.160 \mathrm{t}_{\text {table }}$ value 1.97897 , the significance $0,2 \%$. Then it can be inferred that the $\mathrm{H} 2$ are received or there is partially influence between Inventory Turnover Ratio against the Return On Investment.

Research results are in line with research Saputra (2013) and Saputra R. P.(2013) stating that the Inventory Turnover Ratio effect on ROI. While the results of this study are inconsistent with research Elnisyah (2014), Dewi \& Rahayu (2016) stating that the Inventory Turnover Ratio has no effect against a Return On Investment.

The results of this study indicate that Inventory Turnover Ratio affect the Return On Investment. This is due to the production of industrial companies could capitalize on the quantity and quality of supplies with good which makes increasing sales and will have an impact on the company's profit gain

The Third Hypotesis (H3) : The influence of Cash Turnover against the Return On Investment

This test aims to prove whether there is a partial influence between Cash Turnover 
against a Return On Investment. Based on the test results in table 7 above obtained $t_{\text {coun }}$ value -1.260 while $\mathrm{t}_{\text {table }}$ value 1.97897 , the significance $12 \%$. Then it can be inferred that the $\mathrm{H} 3$ denied or there are no partially influence between the Cash Ratio against the Return On Investment. Research results are in line with research Dewi \& Rahayu (2016) found that Cash Turnover has no effect against ROI. While the results of the research Anggraeni \& Prijati (2017) states the Cash Turnover affect ROI.

While in this study explains that the company hasn't been able to maximize the use of its assets, resulting in low sales turnover. The company also hasn't been able to avail cash with either. It causes the company's profitability will be reduced.

The Fourth Hypotesis (H4) : Influence of the Debt To Equity Ratio against the Return On Investment

This test aims to prove whether there is a partial influence between the Debt To Equity Ratio against the Return On Investment. Based on the results of the $t$ test on the table 7 above obtained $t_{\text {count }}$ value registration -0.850 while $\mathrm{t}_{\text {table }}$ value 1.97897 , the significance $39,7 \%$. Then it can be inferred that the H1 denied or there are no partially influence between the Debt To Equity Ratio against the Return On Investment. Debt To Equity Ratio is a comparison between the total debt with equity (capital). The lower the value of the Debt To Equity Ratio the value of ROI will also be low, so that will affect the company's earnings gains. It caused the company will pay all obligations using its capital to pay down debt. As a result the company's profit will decrease because of capital that should be used to develop the effort used to cover company obligations that must be fulfilled immediately, so that the company's income in obtaining profit will decrease.

The results of this study are in line with research Elnisyah (2014) stating that the Debt To Equity Ratio has no effect against a Return On Investment. These results are inconsistent with research Febriano (2014) which found that the Debt To Equity Ratio has no effect against a Return On Investment.

Table 8 The Results of Coefficient Determination $\left(\mathbf{R}^{2}\right)$ Test

\begin{tabular}{ccccc}
\hline Model & $\mathbf{R}$ & $\mathbf{R}^{2}$ & Adjusted $\mathbf{R}^{2}$ & Description \\
\hline 1 & 0,721 & 0,520 & 0,505 & $\begin{array}{c}\text { The independent variables can explain the } \\
\text { dependent variable }\end{array}$ \\
\hline
\end{tabular}

\section{The Results of Coefficient Determination $\left(\mathbf{R}^{2}\right)$ Test}

Determination of coefficient of test used to find out how far the capability model in the dependent variables that describe the variations are examined. The value of the coefficient of determination is seen from the magnitude of the adjusted $r$ square, with values ranging between zero and one, getting closer to one then it can be said that the better the regression model. Determination of coefficient of test results can be presented in the following table:

Based on the results of the calculation of the coefficient determination test in table 8 Adjusted R Square value of 0.505 . This value means that the independent variables the dependent variable can explain of $50.5 \%$ while the rest of $49.5 \%$ are influenced by variables other than the research model.

\section{CONCLUSIONS AND SUGGESTIONS}

This research aims to examine and analyze the influence of Current Ratio, Inventory Turnover Ratio, Cash Turnover and Debt To Equity Ratio against the Return On Investment in the production of industrial companies listed on the stock exchange of Malaysia year 2016. The dependent variables in the study is represented by the Return On Investment. While the independent variable using a type of financial ratios Current Ratio i.e. Turnover Ratio, Inventory Turnover, Cash and Debt To Equity Ratio. The population of the research that is all industrial production registered in Malaysia stock exchange year 2016. Sampling using a purposive sampling technique. This research using a sample as many as 132 companies. Methods of data 
analysis used in the study was multiple linear regression test. The results of this study indicate that the variable Current Cash Turnover Ratio, and Debt To Equity Ratio has no effect against a Return On Investment. While variable Inventory Turnover Ratio effect on Return On Investment. Determination of coefficient of test results can be known that independent variables the dependent variable can explain of $50.5 \%$ while the rest of $49.5 \%$ are influenced by variables other than the research model.

Based on the results of testing a hypothesis which States that the Current Ratio has no effect against the Return On Investment is not supported by empirical evidence. Hypothesis
2 used in the study stated that the Inventory Turnover Ratio influence on Return On Investment supported by empirical evidence. Whereas hypotheses 3 and 4 which suggest that Cash Turnover and Debt To Equity Ratio have no effect on the Return On Investment are not supported by empirical evidence.

Suggestions in this study include 1) for researchers can then add other ratio-ratio is expected to be more accurate in the influence of Return On Investment, not only using the ratio-the ratio of common, 2) to researchers next expected using a sample group of other companies, so that research results can be generalized in other companies.

\section{REFERENCE}

Anggraeni, D. P., \& Prijati. (2017). Pengaruh Efektivitas modal kerja terhadap ROI perusahaan manufaktur yang terdaftar di BEI. Jurnal Ilmu dan Riset Manajemen .

Dewi, L., \& Rahayu, L. (2016). Pengaruh Perputaran Modal Kerja terhadap Profitabilitas perusahaan Manufaktur di Bursa Efek Indonesia. Jurnal Ilmu dan Riset Akuntansi .

Elnisyah, F. (2014). Pengaruh Current Ratio, Quick Ratio, Debt Ratio,Debt To Equity Ratio dan Inventory Turnover terhadap Return On Investment pada perusahaan Food and Beverage yang terdaftar di Bursa Efek Indonesia periode 2010-2012. Jurusan Akuntansi Fakultas Ekonomi Universitas Maritim Raja Ali Haji .

Febriano, A. (2014). Analisis faktor-faktor yang berpengaruh terhadap kinerja keuangan (Perusahaan Telekomunikasi yang Go Public di BEI). Universitas Dian Nuswantoro .

Fitri, M. C., Supriyanto, A., \& Abrar. (2016). Analysis of Debt To Equity Ratio, Firm Size, Inventory Turnover, Cash Turnover, Working Capital Turnover and Current Ratio to profitability Company (Study on mining companies listed in BEI period 2010-2013). Journal of Accounting Volume 2 No 2 .

Ghozali, I. (2009). Aplikasi Analisis Multivariate dengan program SPSS. Edisi keempat.

Kasmir. (2010). Pengantar Manajemen Keuangan. Jakarta: Kencana Prenada Media Group.

Pamungkas, N. N., \& Sukirno. (2016). Analisis faktor-faktor yang mempengaruhi Return On Investment (ROI). Jurnal Profita Edisi 8 .

Saputra, I. (2013). Pengaruh Quick Ratio, Current Ratio, Inventory Turnover terhadap Return On Investment pada perusahaan Garmen dan Tekstil yang terdaftar di Bursa Efek Indonesia. Jurnal Ekonomi Manajemen Vol.10 No.1 .

Saputra, R. P. (2013). Pengaruh Debt To Total Assets, Working Capital Turnover, Cash Ratio, Inventory Turnover dan Receivable Turnover Terhadap ROI pada perusahaan Manufaktur Bidang Industri Barang Konsumsi. Fakultas Ekonomi dan Bisnis, Universitas Dian Nuswantoro,Semarang,Indonesia . 